\title{
Determination of Fruit Cracking Rates in Some Pomegranate (Punica granatum L.) Genotypes Growed Non-Irrigated Conditions ${ }^{\#}$
}

\author{
Emine Açar ${ }^{1, a}$, Melike Cengiz ${ }^{2, b, *}$, Yıldız Aka Kaçar ${ }^{1,2, c}$, Ahsen Işık Özgüvenº,d \\ ${ }^{I}$ Department of Biotechnology, Institute of Natural and Applied Science, Çukurova University, 01330 Adana, Turkey \\ ${ }^{2}$ Department of Horticulture, Institute of Natural and Applied Science, Çukurova University, 01330 Adana, Turkey \\ ${ }^{3}$ Department of Plant Production and Technologies, Faculty of Agricultural Sciences and Technologies, Cyprus International University, \\ North Cyprus \\ *Corresponding author
}

\begin{tabular}{|c|c|}
\hline A R T I C L E I N & B S T R A C T \\
\hline $\begin{array}{l}{ }^{\#} \text { This study was presented as an online } \\
\text { presentation at the } 2^{\text {nd }} \text { International } \\
\text { Journal of Agriculture - Food Science } \\
\text { and Technology (TURJAF 2021) } \\
\text { Gazimağusa/Cyprus } \\
\text { Research Article }\end{array}$ & $\begin{array}{l}\text { Pomegranate (Punica granatum L.) is a tropical and subtropical climate plant with high economic } \\
\text { value and nutritional content. Having valuable phytochemicals in terms of health caused an increase } \\
\text { in demand for pomegranate consumption and this situation accelerated pomegranate production. } \\
\text { However, global warming and climate changes are among the factors limiting the production of } \\
\text { pomegranate. Especially abiotic stress factors caused by adverse ecological conditions cause } \\
\text { significant economic losses in pomegranate production. Drought stress, which is one of these } \\
\text { negativities, causes fruit cracking problem, which is one of the important problems in pomegranate } \\
\text { production. Minimizing the fruit cracking problem, which causes economic losses, is possible by } \\
\text { breeding varieties that are resistant to under non-irrigated conditions. Determining the resistance of } \\
\text { the cultivars to be used in breeding programs against fruit cracking will allow the development of } \\
\text { elite cultivars. For this purpose, it was aimed to determine the fruit cracking rates of } 30 \text { different } \\
\text { pomegranate genotypes in the Pomegranate Genetic Collection of Çukurova University, Faculty of } \\
\text { Agriculture, Department of Horticulture, under non-irrigated conditions. A correlation was made } \\
\text { between the cracking rates of the genotypes and the amount of soluble solids content (SSC). } \\
\text { According to the correlation analysis between the cultivars, there is no statistically significant } \\
\text { difference between the SSC and the cracking rate. However, a weak negative correlation was } \\
\text { determined between SSC-cracking rate (-0,1132). In the light of the pomological data obtained, it } \\
\text { was determined that } 8 \text { pomegranate genotypes grown under non-irrigated conditions had a fruit } \\
\text { cracking rate of } 40 \% \text { - } 85 \% \text {, cracking rates were below } 10 \% \text { in } 8 \text { pomegranate genotypes and no } \\
\text { fruit cracking was observed in } 6 \text { genotypes. As a result of the analysis, it was observed that drought } \\
\text { stress was effective on the fruit cracking rate or the exacerbation of the fruit cracking rate, but the } \\
\text { resistance level of some genotypes against the fruit cracking problem was high. }\end{array}$ \\
\hline
\end{tabular}

resistance level of some genotypes against the fruit cracking problem was high.

\section{Introduction}

Pomegranate (Punica granatum L.) is one of the oldest plant species with its cultural history, which was cultivated approximately 5000 years ago due to its attractive fruits (Yuan et al., 2018). The homeland of pomegranate is Southwest Asia, South Asia, Middle East, Iran, Afghanistan, South Caucasus and Anatolia (Y1lmaz and Özgüven, 2009). Due to its high nutritional value and its resistance to different ecological conditions, it has spread to a wide geography outside its homeland (Mars, 2000; Zhao et al, 2013). The worldwide demand for pomegranate is increasing year by year, and in pomegranate production respectively, India (1.789.310 tons), Iran (1.000.000 tons),
China ( 800.000 tons), Turkey (537,000 tons). Due to being the homeland of pomegranate and having suitable climate and geographical features, as far as it's production is concerned, Turkey is the among the list of leading countries (Özgüven \& Y1lmaz, 2000; Simsek et al, 2017). Having valuable phytochemicals in terms of health caused an increase in demand for pomegranate consumption and this situation accelerated pomegranate production.

The increase in pomegranate cultivation has led to the current problems. Global warming and climate changes are among the factors limiting the production of pomegranate. Especially abiotic stress factors caused by adverse 
ecological conditions cause significant economic losses in pomegranate production. Drought stress, causes fruit cracking problem, which is one of the important problems in pomegranate production. Fruit cracking in pomegranate is observed during the fruit maturity period and the cracking rate increases as the maturity period progresses. Fruit cracking usually causes physical damage to the fruit skin by the increase in the water content of the pomegranate seeds during the ripening period and the internal development of the fruit by creating pressures on the peel, and there are many different causes (Y1lmaz and Özgüven, 2012). Fruit cracking rates may differ in different varieties grown under the same ecological and cultural conditions (Yılmaz \& Özgüven, 2012; Khadivi-Khub, 2015). Minimizing the fruit cracking problem, which causes economic losses, is possible by breeding varieties that are resistant to under non-irrigated conditions.
Determining the resistance of the cultivars to be used in breeding programs against fruit cracking will allow the development of elite cultivars. For this purpose, it was aimed to determine the fruit cracking rates of 30 different pomegranate genotypes in the Pomegranate Genetic Collection of Çukurova University, Faculty of Agriculture, Department of Horticulture, under non-irrigated conditions.

\section{Material and Method}

\section{Plant Material}

In this study, Pomegranate Genetic Collection of Çukurova University, Faculty of Agriculture, Department of Horticulture was used. Varieties in the Pomegranate Genetic Collection were used to determine cracking rates and SSC rates (Table 1).

Table 1. Pomegranate varieties and quality traits used in the study

\begin{tabular}{l|ll|l}
\hline \multicolumn{1}{c|}{ Variety Name } & \multicolumn{1}{c|}{ Quality Traits } & \multicolumn{1}{c}{ Variety Name } & \multicolumn{1}{c}{ Quality Traits } \\
\hline Naznar & Sweet/soft & İzmir-1453 & Sweet/soft \\
Canernar 11 & Sourish/ soft & Canernar 7 & Sourish/soft \\
$17 / 67$ & Sour/medium soft & İzmir-1445 & Sweet/soft \\
33 N 34 & Sourish/soft & Türkmen & Sweet/medium hard \\
33 N 53 & Sweet/soft & İzmir-23 & Sweet/soft \\
Hicrannar 7 & Sweet/soft & İzmir-8 & Sweet/hard \\
19/147 & Sweet/soft & 33 N 09 & Sourish/hard \\
İzmir-1 & Sweet/soft & Hicaznar & Sourish/hard \\
İzmir-1261 & Sweet/soft & 33 N 16 & Sourish/medium hard \\
Hicrannar 5 & Sweet/soft & İzmir-1479 & Sweet/soft \\
01 N 04 & Sweet/soft & İzmir-1267 & Sweet/soft \\
İzmir-16 & Sweet/hard & İzmir-12 & Sweet/soft \\
İzmir-15 & Sweet/soft & İzmir-1265 & Sweet/soft \\
07 N 04 & Sweet/hard & İzmir-10 & Sweet/hard \\
İzmir-26 & Sweet/soft & $18 / 19$ & - \\
\hline
\end{tabular}
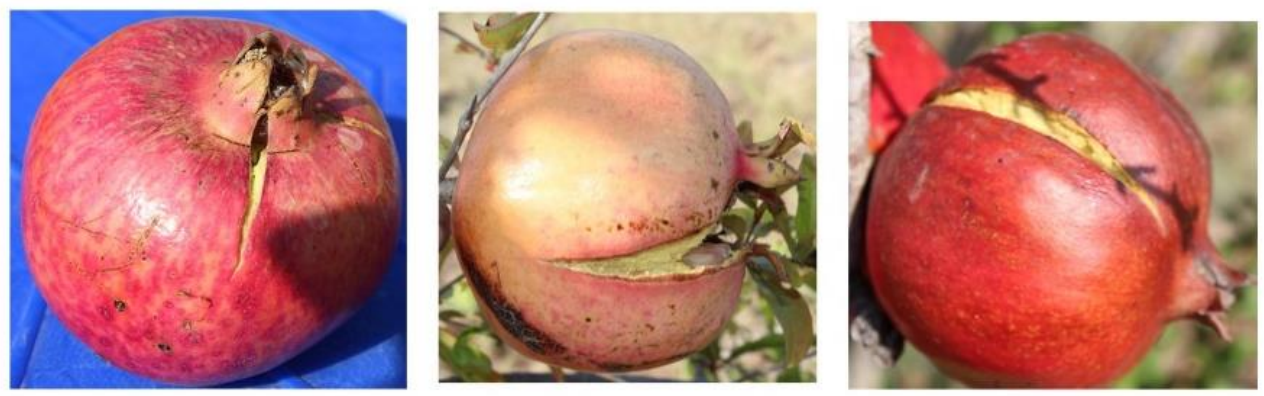

Figure 1. Some fruits with cracking

\section{Method}

Determination of Cracking Rate

The fruits were checked regularly until the harvest period. In pomegranate cultivars, cracked and non-cracked fruits were counted in order to determine the cracking rates of the cultivars. The fruit cracking rate of the cultivars was determined by proportioning the number of cracked fruit to the total number of fruit.

SSC (Soluble solids content) Determination of Rates

Within the scope of biochemical analysis, soluble solids content (SSC) analysis was performed by using fruit juice samples of the cultivars. SSC were determined by extracting and mixing one drops of juice from the each fruit into a digital refractometer and displayed as $\%$.

\section{Results and Discussions}

In order to determine the fruit cracking rates and SSC of pomegranate cultivars under non-irrigated conditions were used some pomegranate cultivars from the Pomegranate Genetic Collection of Çukurova University, Faculty of Agriculture, Department of Horticulture. The cracking rates of the cultivars were determined (Figure 2) and the SSC amounts of the cultivars were determined by using the arils of pomagranate cultivars (Figure 3). Regular observations made within the scope of the study started as of March 2018 and continued as of June, July, August, September and October. Observations were made at regular intervals until the harvest period. During the 
harvest period, fruit cracking rates of the varieties in the collection were determined. The cracking rate was calculated by looking at the sample with at least 10 fruits and above. SSC values were determined by using the grains of the fruit, with at least 3 replications for each cultivar.

When the fruit cracking rates of the cultivars were examined, it was determined that the fruit cracking rates of the four cultivars were between $50 \%$ and $85 \%$. It was determined that the highest cracking rate of the cultivars was Naznar with $85 \%$ and Canernar 11 with $80 \%$. While $74 \%$ cracking was observed in 17/67 genotype, 50\% fruit cracking rate was detected in $33 \mathrm{~N} 34$ cultivar. It was observed that the cracking rates of 16 varieties observed within the scope of the study varied between $50 \%$ and $10 \%$. While it was determined that 33 N 53 cultivar had $47 \%$ cracking rate, 18/19 cultivar 43\%, 19/147 cultivar $41 \%$ cracking rate, while İzmir-1 cultivar had $40 \%$ cracking rate. With the analysis, it was determined that Hicrannar 5 variety had 35\% cracking rate, İzmir-15 and $07 \mathrm{~N} 04$ variety had $28 \%$ cracking rate, İzmir-26 variety had $19 \%$, İzmir-1261 variety $16 \%$, Hicrannar 7 variety $14 \%$, İzmir1453 and Canernar 7 variety $10 \%$. Data obtained as a result of observations when examined, the cracking rate of 8 cultivars was below $10 \%$. Fruit cracking was detected $9 \%$ in İzmir-1445 and Türkmen varieties, 8\% in İzmir-23 variety, 7\% in İzmir-8 variety, 6\% in $33 \mathrm{~N} 09$ variety, 5\% in Hicaznar variety, $3 \%$ in $33 \mathrm{~N} 16$ variety and 2\% in Izmir1479. As a result of the observations, the fruit cracking rate was found to be 0 in 6 varieties. Varieties without cracking are İzmir-1297, İzmir-1265, İzmir-10, İzmir-16, İzmir-12 and $01 \mathrm{~N} 04$ pomegranate varieties.

SSC amounts of the cultivars were determined by using the arils of pomagranate cultivars. When the SSC values of the genotypes were examined, it was determined that the SSC values of the five genotypes were between $20.06 \%$ and $24.95 \%$. It was observed that the highest SSC value of the genotypes was İzmir-26 with $24.95 \%$ and İzmir-1479 with $23.86 \%$. While $21.23 \%$ SSC value was obtained in Türkmen genotype, it was seen as $21 \%$ in $18 / 19$ genotype. While the SSC value of the remaining 20 genotypes is over $15 \%$, SSC belonging to the İzmir-1453 with $14.9 \%$, Hicrannar 5 with $14.3 \%$, $07 \mathrm{~N} 04$ with 14.2\%, İzmir-1445 with $13.65 \%$, and Hicaznar with $13.4 \%$ genotypes values are below $15 \%$.

According to the correlation analysis between the cultivars, there is no statistically significant difference between the SSC and the cracking rate. However, a weak negative correlation was determined between SSCcracking rate (Table 2 ).

Cracking rate (\%)

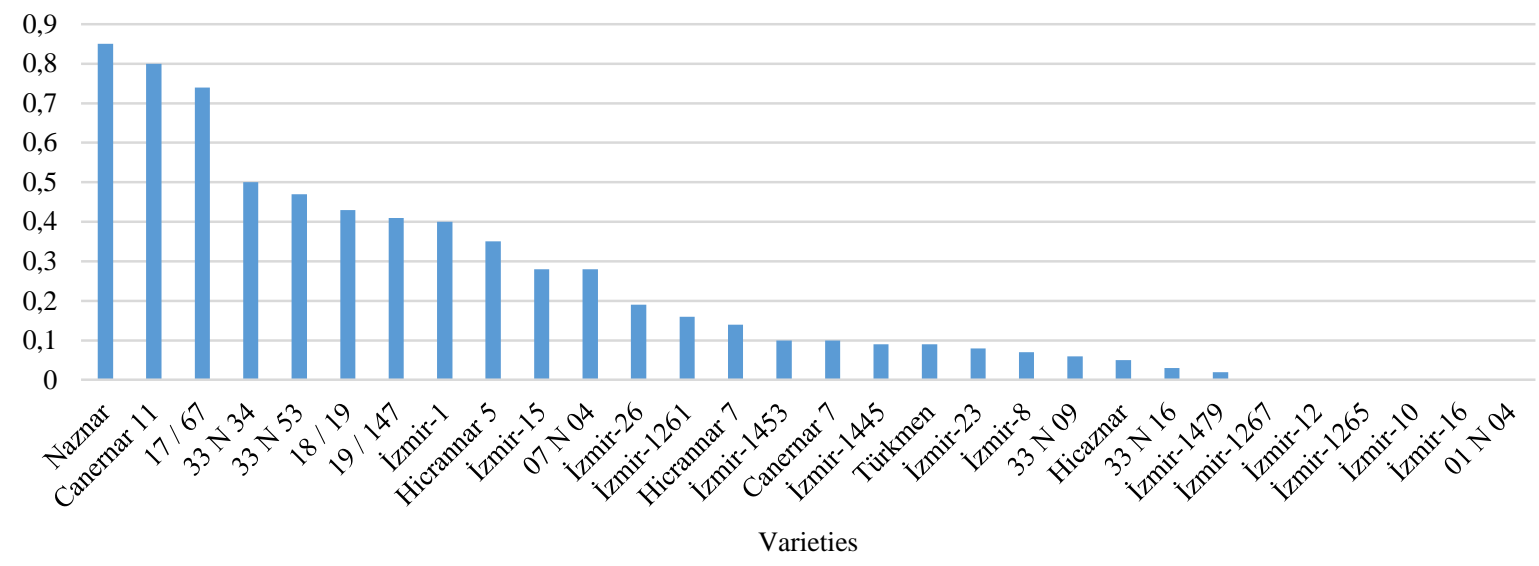

Figure 2. Varieties cracking rates

$\operatorname{SSC}(\%$ Brix $)$

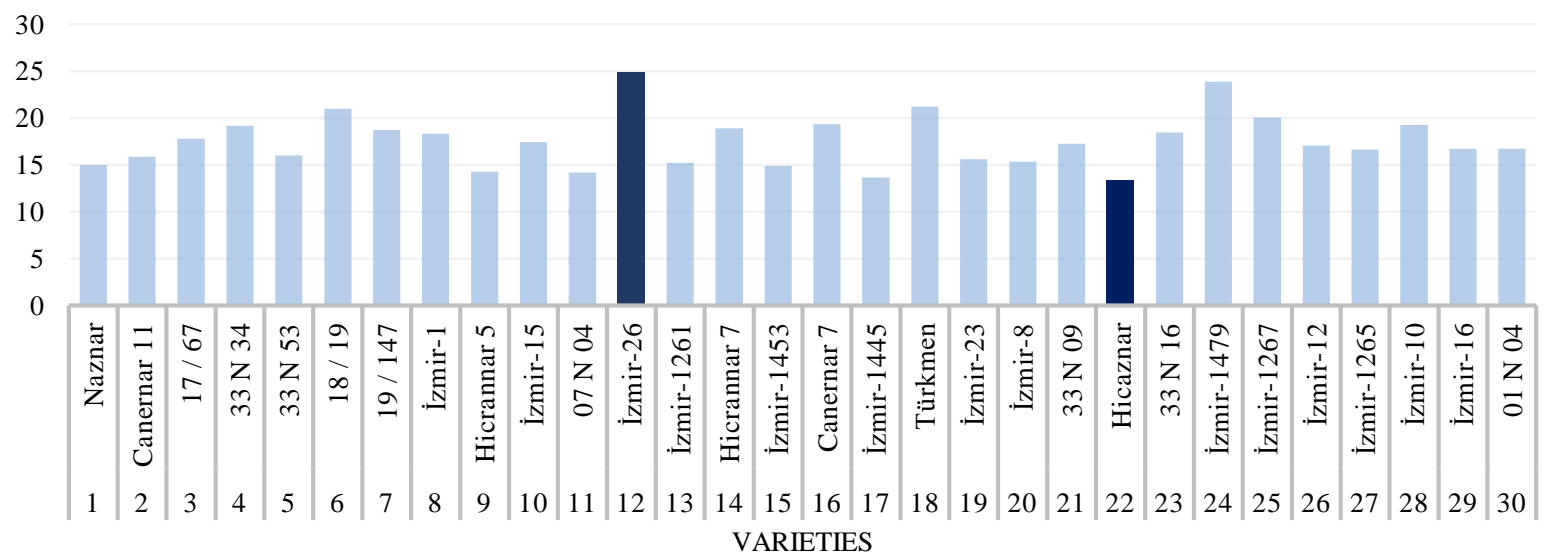

Figure 3. SSC values of varieties 
Table 2. Correlation of SSC-cracking rate

\begin{tabular}{l|cc}
\hline & V1 & V2 \\
\hline SSC (\% Brix) (V1) & 1.0000 & -0.1132 \\
Cracking rate (\%) (V2) & & 1.0000 \\
\hline
\end{tabular}

There are many studies reporting that fruit cracking in pomegranate is due to many factors. It has been reported that the effects of especially ecological conditions, cultural practices and genetic factors are intense in fruit cracking. There are ecological conditions that cause irregular precipitation, daily or seasonal temperature differences or increase the severity of cracking (Khadivi-Khub, 2015; Singh et al, 2020).

When the data we obtained within the scope of the study are examined, it is seen that the fruit cracking rates are high in most of the existing varieties. It is thought that the reason for the high cracking rates of the cultivars may be the negative effects of ecological conditions. Especially the negative ecological conditions caused changes in the water content of the fruit peel and it is thought that fruit cracking rates have increased due to these changes. As a matter of fact, it has been reported that irregular precipitation causes irregularities in the water content of the fruit peel and this irregular water content reduces the resistance of the fruit peel and causes cracking. In addition, the decrease in air humidity has been reported as an ecological factor that causes a decrease in the water content of the fruit peel and causes cracks in the fruit skin (Singh et al., 2014).

Daily or seasonal temperature differences are also among the factors that change the fruit peel water content or decrease the fruit peel water content. The most important negative effect of temperature differences is that it affects the respiration and transpiration of the plant (Singh et al, 2014). It is thought that all the aforementioned problems cause a decrease in the water content of the fruit peel and an increase in the fruit cracking rate or fruit cracking rate. Negative ecological conditions create stress in the plant.

Stress conditions cause many physiological problems in the plant as well as fruit cracking or exacerbation of fruit cracking rate. As a matter of fact, Y1lmaz and Özgüven (2006), in a study they conducted on pomegranate, reported that the level of ABA (Abscisic Acid) hormone in the peel of cracked fruits was higher than in fruits that did not crack. They emphasized that the reason for the higher ABA level in cracked fruits is a stress response of the plant against physiological negativities.

When the data obtained within the scope of the study are examined, the majority of the varieties with high fruit cracking rate are the pome varieties. Soft or hard traits is a genetic features that can cause fruit cracking or an increased cracking rate. It is thought that there is a correlation between the severity of the cracking rate of the cultivars and the soft seed trait. The state of hard or soft seed results from differences in the amount of lignin of the tissues (Sarkhosh et al, 2011; A. Zarei et al, 2013, 2016; Akgöl, 2017; Xue et al, 2017; Khadivi et al, 2018; Luo et al, 2020; Zhang et al, 2020).

Lignin is a secondary compound that forms the structure of the cell wall and provides cellular durability. It is a polymer that gives elasticity to the cell, especially during cell development. Lignin also participates in the formation of the cuticular structure and the structure of the epidermis layer. There are many studies stating that the lignin biosynthesis mechanism plays an active role in the formation of pomegranate soft and hard arils. The difference in the amount of lignin between pomegranate varieties is a genetic feature and helps them to gain different properties not only in the seed structure, but also in other tissues such as fruit peel, cuticle layer and epidermis. It has been reported that pomegranate fruits contain lower lignin than stone fruits, and this situation is in parallel with the lignin content of the fruit peel tissue (Sarkhosh et al, 2011; A. Zarei et al, 2013, 2016; Akgöl, 2017; Xue et al, 2017; Khadivi et al, 2018; Luo et al, 2020; Zhang et al, 2020).

Studies have reported that pomegranate cultivars with a high lignin content are more resistant to biotic and abiotic stress conditions than pomegranate cultivars, and this has been confirmed by molecular studies (A. Zarei et al, 2016; Zhang et al, 2020). In this study, the reason for the high cracking rate in soft-seed cultivars can be explained by the low lignin content and the sensitivity of this genetic feature to the plant.

The arils of pomegranates contain considerable amounts of acids, sugars, vitamins, polysaccharides, polyphenols and important minerals (Al-Maiman and Ahmad, 2002). In present study, SSC of cv. 'Hicaznar' at three development stages were $6.16 \%, 10.38 \%$ and $15.84 \%$. Significant variations in SSC (11-23\%) of pomegranates have been reported over the years by various researchers (Ercan et al., 1992; Yilmaz et al., 1992; Polat et al., 1999; Tibet and Onur, 1999; Al-Maiman and Ahmad, 2002; Kazankaya et al., 2003; Yildiz et al., 2003; Ozkan, 2005; Gozlekci et al., 2011).

When the data obtained in the study are examined, most of the varieties with high cracking rate are sweet varieties. It has been reported that the sugar content in the fruit is a physiological condition that causes fruit cracking or the exacerbation of the fruit cracking rate, and that the sugar rate in the fruit leads to osmotic differences, leading to fruit cracking or increasing the fruit cracking rate (Mir et al, 2012; Khadivi-Khub, 2015; Correia et al., 2018). As a matter of fact, as a result of the analysis, it is estimated that most of the varieties with high cracking rates are sweet pomegranate varieties and this physiological condition is the basis for the high cracking rates in sweet varieties.

There is no detailed information about the varieties used in the study and the cracking rates were determined. For this reason, cracking rates of some cultivars were determined for the first time. If the cracking rates of some pomegranate cultivars are examined within the scope of the study, it is seen that the cracking rates of some pomegranate cultivars and the cracking rates obtained from some previous studies show parallelism. Especially when the cracking rates are compared according to the varieties, it is seen that the cracking rates of İzmir-15 variety, İzmir26 variety and İzmir-23 variety are higher than the other varieties, and the cracking rates of İzmir-16 and İzmir-10 varieties are lower. When the results obtained within the scope of the study are examined, it is seen that the cracking rates of the cultivars are close to the cracking rates stated in the literature sources and the values show parallelism.

Y1lmaz (2005) analyzed the fruit cracking after harvesting in pomegranate anatomically and 
physiologically, and examined cracked and uncracked fruits in many different parameters. The study was carried out in 2001-2003 and İzmir-10, İzmir-15, İzmir-16, İzmir23, İzmir-26, $33 \mathrm{~N} 16$ and Hicaz varieties were used in the experiment. In the study, it was reported that the cracking rates of the cultivars changed according to the years, but it was reported that the cultivars with the highest cracking rate were İzmir-15 and İzmir-26, and the varieties with the lowest cracking rate were İzmir-16. When the rates of İzmir-15, İzmir-26 and İzmir-23 cultivars were examined, the highest fruit cracking rates were observed in these cultivars. Again, the lowest cracking rates were seen in Hicaz, İzmir-10 and İzmir-16 varieties. In the comparison made on the basis of the cracking rates of the cultivars, it is seen that the İzmir-15 cultivar has a higher cracking rate compared to the other cultivars, while the İzmir-16 cultivar shows no cracking and the values obtained are close to the literature values.

Özgüven et al. (2000) conducted a study on cracking rates in pomegranate at Koruklu Research Station. According to the results of the study, cracking rates are $44 \%$ for İzmir-23, $16.1 \%$ for İzmir-15, $13.3 \%$ for Hicaz, $12.7 \%$ for İzmir-26, $0.2 \%$ for İzmir-10 and İzmir-16. 0.1\% of the cultivar.

Özgüven et al. (1997) carried out adaptation studies on pomegranate in the Southeastern Anatolia Region. According to the test results, the cracking rates were respectively $20.1 \%$ for İzmir-10, 20.6\% for İzmir-15, $21.0 \%$ for İzmir-26, $20.6 \%$ for Hicaz, $13.1 \%$ for İzmir-23 and $0.9 \%$ of İzmir-16 variety.

The study conducted by Y1lmaz and Özgüven (2006), it was found that the fruit cracking rates ranged between $0.0 \%$ and $46.3 \%$, whereas, the average fruit cracking rates of the varieties were recorded at $21.3 \%$ in Izmir-15, 34\%, İzmir-10 variety, $0.5 \%$ in İzmir-16 variety, $20.9 \%$ in İzmir23 variety, 9.2\% in İzmir-26 variety and $12.7 \%$ Hicaz variety respectively. Furthermore, in the trial that lasted for two years, it was reported that the high differences were observed between the cracking rates in İzmir-15 variety according to years, $9.1 \%$ in the first year, $33.4 \%$ cracking rate in the second year in İmir-15 variety respectively.

It has been reported by numerous studies that fruit cracking rates vary from year to year and are affected by many factors. The reason why the cracking rates we obtained in our study do not exactly overlap with the literature sources shows that the problem of fruit cracking in pomegranate depends on many different factors, including physiological, anatomical and genetic.

\section{References}

Akgöl M. 2017. Nar'da (Punica granatum L.) Yumuşak-Sert Çekirdek Oluşum Mekanizmasının Moleküler, Histolojik ve Biyokimyasal Yöntemlerle Araştırılması, Çukurova Üniversitesi, Fen Bilimleri Enstitüsü, Biyoteknoloji Anabilim Dalı (Doktora Tezi, 182 s.).

Al-Maiman SA, Ahmad D. 2002. Changes in Physical and Chemical Properties During Pomegranate (Punica Granatum L.) Fruit Maturation. Food Chem 76: 437-441.

Correia S, Schouten R, Silva AP, Gonçalves B. 2018. Sweet Cherry Fruit Cracking Mechanisms and Prevention Strategies: A Review. Scientia Horticulturae, 369: 377-240.
Ercan N, Ozvardar S, Gonulsen N, Baldiran E, Onal K., Karabiyik N. 1992. Determination of Suitable Pomegranate Cultivars for Aegean Region. Proceedings of 1st National Horticultural Congress. 13-16 October 1992, İzmir-Turkey (in Turkish).

Kazankaya A, Gundogdu M, Askin MA, Muradoglu F. 2003. Fruit Attributes of Local Pomegranates Grown in Pervari. Proceedings of 4th National Horticultural Congress. 8-12 September 2003, Antalya-Turkey (in Turkish).

Khadivi A, Ayenehkar D, Kazemi M, Khaleghi A. 2018. Phenotypic and Pomological Characterization of a Pomegranate (Punica granatum L.) Germplasm Collection and Identification of the Promising Selections. Scientia Horticulturae, 234: 45-238.

Khadivi-Khub A. 2015. Physiological and Genetic Factors Influencing Fruit Cracking. Acta Physiologiae Plantarum, 37(1): 1718.

Luo X, Li H, Wu Z, Yao W, Zhao P, Cao D, Yu H, Li K, Poudel K, Zhao D. 2020. The Pomegranate (Punica granatum L.) Draft Genome Dissects Genetic Divergence Between Softand Hard-Seeded Cultivars. Plant Biotechnology Journal, 18(4): 955-968.

Mars M. 2000. Pomegranate Plant Material: Genetic Resources and Breeding, a Review. Options Mediterraneennes Serie A, 42: 55-62.

Mir MM, Umar I, Mir SA, Rehman MU, Rather GH, \& Banday SA. 2012. Quality Evaluation of Pomegranate Crop-A Review. International Journal of Agriculture Biology, 14(4): 134-143.

Özgüven AI, Çetiner S, Ak BE, Yılmaz C. 1997. Güneydoğu Anadolu Bölgesinde Değişik Nar Çeşitlerinin Adaptasyonu Üzerine Araştırmalar (II. Araştırma Dilimi). Ç.Ü. Ziraat Fakültesi Genel Yayın No: 192, GAP Yayınları No: 112, Adana, 29 s.

Özgüven A, Y1lmaz C. 2000. Pomegranate Growing in Turkey. Options Mediterraneennes, Serie A: Seminaires Mediterraneennes, 42: 41-48.

Ozkan Y. 2005. Investigations on Physical and Chemical Characteristics of Some Pomegranate Genotypes (Punica Granatum L.) of Tokat Province in Turkey. Asian J Chem 17: 939-942.

Ozlekc1 SG, Ercıslı S, Okturen F, \& Sonmez S. 2013. PhysicoChemical Characteristics at Three Development Stages in Pomegranate cv. 'Hicaznar'. Notulae Botanicae Horti Agrobotanici Cluj-Napoca, 39(1): 241-245.

Polat AA, Durgac C, Kamiloglu O, Mansuroglu M, Ozturk G. 1999. Studies on Determination of Pomological Characteristics of Some Pomegranate Types Grown in Kırıkhan District of Hatay Province. Proceedings of $3^{\text {nd }}$ National Horticultural Congress. 14-17 September 1999, AnkaraTurkey (in Turkish).

Sarkhosh A, Zamani Z, Fatahi R, Hassani ME, Wiedow C, Buck E, Gardiner SE. 2011. Genetic Diversity of Iranian Soft-Seed Pomegranate Genotypes as Revealed by Fluorescent-AFLP Markers. Physiology and Molecular Biology of Plants, 17(3): 305-311.

Simsek O, Donmez D, Kacar YA. 2017. RNA-Seq Analysis in Fruit Science: A Review. Am. J. Plant Biol, 2(5): 1.

Singh A, Burman U, Santra P, Morwal BR. 2014. Fruit Cracking of Pomegranate and its Relationship with Temperature and Plant Water Status in Hot Arid Region of India. J. Agrometeor, 16: 24-29.

Singh A, Shukla AK, Meghwal PR. 2020. Fruit Cracking in Pomegranate: Extent, Cause, and Management-A Review. International Journal of Fruit Science, 1-20.

Tibet H, Onur C. 1999. Adaptation of Pomegranate (Punica granatum L.) Cultivars in Antalya Region. Proceedings of 3th National Horticultural Congress. 14-17 September 1999, Ankara-Turkey (in Turkish). 
Xue H, Cao S, Li H, Zhang J, Niu J, Chen L, Zhang F, Zhao D. 2017. De Novo Transcriptome Assembly and Quantification Reveal Differentially Expressed Genes Between Soft-Seed and Hard-Seed Pomegranate (Punica granatum L.). PloS One, 12(6), e0178809.

Yildiz K, Muradoglu F, Oguz HI, Yilmaz H. 2003. Pomological Characteristic of Pomegranate Varieties Grown in Hizan Town of Bitlis. Proceedings of 4th National Horticultural Congress. 8-12 September 2003, Antalya- Turkey (in Turkish).

Yilmaz C, Ozguven AI. 2006. Hormone Physiology of Preharvest Fruit Cracking in Pomegranate (Punica granatum L.). Acta Horticulturae, 727: 545-550.

Yılmaz C, Özgüven AI. 2009. Türkiye'deki Nar Genetik Kaynakları. III. Ulusal Üzümsü Meyveler Sempozyumu, 1012 Haziran 2009, Kahramanmaraş.

Yilmaz C, Özgüven AI. 2012. Narda (Punica granatum L.) Meyve Çatlaması. Hasat Yayıncılık.
Yılmaz C. 2005. Narda Derim Öncesi Meyve Çatlamasının Anatomisi ve Fizyolojisi. Çukurova Üniversitesi, Fen Bilimleri Enstitüsü (Doktora Tezi, 277 s.).

Yuan Z, Fang Y, Zhang T, Fei Z, Han F, Liu C, Liu M, Xiao W, Zhang W, Wu S, Zhang M, Ju Y, Xu H, Dai H, Liu Y, Chen Y, Wang L, Zhou J, Guan D, Zheng H. 2018. The Pomegranate (Punica granatum L.) Genome Provides Insights into Fruit Quality and Ovule Developmental Biology. Plant Biotechnology Journal, 16(7): 1363-1374.

Zarei A, Zamani Z, Fatahi R, Mousavi A, Salami SA. 2013. A Mechanical Method of Determining Seed- Hardness in Pomegranate. Journal of Crop Improvement, 27(4): 444-459

Zhang X, Zhao Y, Ren Y, Wang Y, Yuan Z. 2020. Fruit Breeding in Regard to Color and Seed Hardness: A Genomic View from Pomegranate. Agronomy, 10(7): 991.

Zhao X, Yuan Z, Fang Y, Yin Y, Feng L. 2013. Characterization and Evaluation of Major Anthocyanins in Pomegranate (Punica granatum L.) Peel of Different Cultivars and Their Development Phases. European Food Research and Technology, 236(1): 109-117. 